SHADES OF WHITE FLIGHT 



\section{SHADES OF}

WHITE FLIGHT

\section{Evangelical Congregations and Urban Departure}

MARK T. MULDER

RUTGERS UNIVERSITY PRESS

New Brunswick, New Jersey, and London 
Library of Congress Cataloging-in-Publication Data

Mulder, Mark T., 1973-

Shades of white flight : evangelical congregations and urban departure / Mark T. Mulder.

pages $\mathrm{cm}$

Includes bibliographical references and index.

ISBN 978-0-8135-6483-8 (hardcover : alk. paper) — ISBN 978-0-8135-6482-1

(pbk. : alk. paper) - ISBN 978-o-8135-6484-5 (e-book)

1. United States-Race relations - History - 2oth century.

2. Evangelicalism - United States-History - 2oth century. 3. Race-

Religious aspects - Christianity. 4. Identification (Religion). 5. Racism-

United States-History-2oth century. 6. African Americans-Illinois-

Chicago-History - 2oth century-Case studies. 7. Whites - Illinois-

Chicago-Migrations-History-2oth century-Case studies. I. Title.

$\mathrm{E}_{184 . \mathrm{A}_{1} \mathrm{M}_{78} 2015}$

305.80097309' $04-\mathrm{dc} 23$

2014021722

A British Cataloging-in-Publication record for this book is available from the British Library.

Copyright (@) 2015 by Mark T. Mulder

All rights reserved

No part of this book may be reproduced or utilized in any form or by any means, electronic or mechanical, or by any information storage and retrieval system, without written permission from the publisher. Please contact Rutgers University Press, 106 Somerset Street, New Brunswick, NJ 08901. The only exception to this prohibition is "fair use" as defined by U.S. copyright law.

Visit our website: http://rutgerspress.rutgers.edu

Manufactured in the United States of America 
For Dad and Mom, in appreciation of your steadfastness, commitment, faith, and love 
